\title{
THE MANAGEMENT OF SUSTAINABLE COMMUNAL IPAL IN SIMOKERTO SUB-DISTRICT, SURABAYA
}

\author{
Lunariana Lubis $^{1}$, Agus Wahyudi ${ }^{2}$, Deasy Arieffiani ${ }^{3}$ \\ 1,2,3Public Administration, Faculty of Social and Political Sciences, Hang Tuah University Surabaya \\ 1'lunariana.lubis@hangtuah.ac.id, ²agus.wahyudi@hangtuah.ac.id, \\ 3deasy.ariffiani@hangtuah.ac.id
}

\begin{abstract}
IPAL is the development program of wastewater management installation. It is a community-based communal and presumed to prioritize physical development without paying attention to the readiness of human resources at the local level so that some cases in the facilities construction have failed or they are unsustainable. This is a qualitative research by using a case study approach that aims to discuss the community's participation in supporting the implementation of sustainability in communal management of IPAL in RT 01 RW 01, Simokerto sub-district, Surabaya. The data collection technique is conducted through the interview, direct observation, and documentation. The findings are obtained by using sustainable analysis in three aspects, namely economic, environmental, and socio-cultural aspects. The result indicates that in terms of the socio-cultural aspect, communal IPAL is unsustainable. The cause is the component condition of communal IPAL which has less advantage due to non-routine maintenance activities.
\end{abstract}

Keywords: Sustainability, Sanitation facilities, Communal IPAL

\section{INTRODUCTION}

Surabaya is the capital of East Java Province and the second-largest city in Indonesia. The city is one of the important cities in western Indonesia that continues to experience population growth and lifestyle development in its population. The population in Surabaya will continue to increase along with the development in the city. High population growth will increase the use of clean water and approximately $80 \%$ of clean water will turn into wastewater. Of ninety-eight cities in Indonesia, only 11 of them have waterways facilities. About $2 \%$ of urban residents have the access to a centralized sanitation system (Nilandita, Pribadi, Nengse, Auvaria, \& Nurmaningsih, 2019).

The wastewater which is directly thrown away into the water storage and unprocessed will contaminate the environment. $76 \%$ of river pollution in Surabaya is caused by household and apartment waste (Nilandita et al., 2019). To reduce wastewater contamination, it should be processed first before it is thrown away into water storage. Moreover, IPAL operation aims to reduce the level of organic and inorganic pollutants contained in wastewater, so that environmental pollution from domestic waste can be reduced.
The presence of communal IPAL will certainly have a positive impact on improving environmental health (sanitation). The issue of sanitation is one of the important things that must be overcome because it involves the lives of many people. The increasing level of population density in Surabaya implies the emergence of various problems related to sanitation. Poor sanitation system becomes the cause of various diseases, such as typhoid, diarrhea, and cholera. Therefore, IPAL is required to overcome the worst impact of this pollution.

The development process of communal IPAL is applied through the concept of community-based development. It means that the community is involved in each phase of development starting from planning, decision making, establishment, operation, and maintenance. In the establishment and operation of the wastewater process medium, a management institution is usually formed at the community level in which the members are community service users (Afandi, Sunoko, \& Kismartini, 2014).

According to the World Commission on Environmental Development (WCED), 1987 (Harudyawati, 2016), sustainable development has a definition. It defines the development that meets the needs of the present generation 
without compromising the ability of future generations to find their own needs. The statement means that the current development can fulfill the needs of the generation without disturbing the needs of future generations to achieve their needs. The basic principle of this definition is that everyone has the same rights to fulfill the needs, whether they live in the present or in the future time. The concept of sustainable development includes interrelated economic, environmental, and social aspects. The sustainability of the wastewater process currently challenges us to manage wastewater differently. So far, the process has focused on the final result, but it will be changed to resources, costs, and technology optimization.

Technology offers a wide variety of alternatives for wastewater treatment solutions, whereas resources are things that can be utilized for wastewater management because they are easy to get and available in that area for developing and operating wastewater management. Furthermore, sustainability can be seen in the following aspects:

a. Sustainable economy can be interpreted as the use of strategies to utilize the resources optimally so that the balance of accountability and the advantage can be achieved in a long period of time. The main sustainability is focused on social welfare through the allocation and distribution of resources optimally to fulfill human needs. The economical factor also determines the wastewater management technology that will be used. Overall, a sustainable approach economically includes all resources related to social and environmental values. However, the practice of economic sustainability analysis is limited to the financial cost (operation and maintenance, as well as the profits).

b. Sustainable environment refers to the ability of an environmental function to support human needs at the present and in the future time. The existence of the natural environment must be maintained to support the development by providing resources and reducing emissions as efficiently as possible. This aspect aims to maintain environmental sustainability for the long term and the efficient use of environmental resources. Thus, regulation is required to regulate the use of natural resources.

c. Social and cultural factors are difficult to measure, but they have important roles in the application of technology that will be used in wastewater management because the waste will have direct contact with the community. The purpose of socio-cultural sustainability is to fulfill human needs in both spiritual and cultural aspects. As a result, morale and community relations can be established well. Furthermore, it can build the relationship between people, the need for social interaction, and selfdevelopment. At last, it also regulates the surrounding community.

An observation of the maintenance and management of communal IPAL is important to ensure the continuity of IPAL utilization. Therefore, it is expected that there will be a sense of public awareness and caring for environmental health. As a result, the community will understand the appropriate behavior in managing IPAL infrastructure, so that they can utilize IPAL, and it can be used for a long time. For this reason, the study discusses the role of the community in supporting the implementation of sustainable and communal management in IPAL, which is located in RT $01 \mathrm{RW} 01$, Simokerto sub-district, Surabaya.

\section{RESEARCH METHOD}

\subsection{Research Design}

This study uses a qualitative research method with a case study approach (Creswell \& Poth, 2018). The purpose is to understand the management of community-based sanitation facilities in Surabaya. This research shows many empirical facts naturally regarding IPAL as community-based sustainability in RT 01 RW 01, Simokerto sub-district, Surabaya.

Data collection techniques are conducted into three stages (Norman K. Denzin, 2010). The first stage is open and structured interviews in which the questions are focused on the problems so that the information is complete and deep. Interviews with the key informants are given to the officers of Simokerto sub-district in Surabaya, the chairman of RT 01 RW 01, and the community. The second stage is direct and indirect observation formally or informally used to observe activities related to the research theme. The third stage is documentation that aims to obtain secondary data, such as the regulation, decision, archives, and other documents that are relevant to the analysis.

In qualitative research, data analysis is conducted simultaneously with the data collection technique. In analyzing the data, researchers use an interactive model (Matthew B. Miles, A. Michael Huberman, 2014), namely data collection, data reduction, and presentation. Data collection is obtained through interviews, observation, documentation, and other secondary data as complementary materials from the use of observation and interview in qualitative research. Whereas, data reduction is applied by sorting the data in the research field which is 
relevant to the problem and conducted several times during the qualitative research process. Also, a presentation is carried out after the data is summarized. Finally, the conclusion is given after the data is presented that consists of the findings of the research.

\section{RESULT AND DISCUSSIONS}

One of the environmental problems that should be overcome in Surabaya is wastewater. The wastewater that enters directly into water storage without being processed, can cause pollution. As a result, water quality is decreased and contaminated. Furthermore, domestic wastewater management is one of the housing health requirements stated in Kepmenkes No. 892 in the year 1999 (Purwatiningrum, 2018). One of the aspects is the wastewater which is coming from the household, must not pollute water sources. It is expected not to cause the odor and polluting the soil surface. Therefore, a way to process wastewater is important, so that it does not have a bad impact on the environment and health.

One of the approaches in processing domestic wastewater is an integrated method using communal IPAL. The management system means collecting and processing the wastewater before throwing it away into surface water. The wastewater from each source is connected through the pipelines and carrier pipes to the centralized installation.

Most of the wastewater is from the settlements of Simokerto that flows into the river located in Sidotopo Wetan main road. This wastewater is unprocessed. This can lead to a decrease in the quality of water in the river. For this reason, communal IPAL was built for the residents in RT $01 \mathrm{RW}$ 01, Simokerto subdistrict in 2011. The establishment was assisted by PT. Pembangkit Jawa Bali and FTSP-ITS (Widiwati, 2018). Communal IPAL was operated two months after the establishment. The result of processed wastewater from IPAL is used by the residents to water the plants and wash the vehicles.

The sustainability of communal IPAL in RT 01 RW 01, Simokerto sub-district can be described into three aspects, namely economic, environmental, and socio-cultural aspects.

a. Economic aspect.

Economic sustainability can be interpreted as the use of strategies to utilize resources optimally so that the balance of accountability and the advantage can be achieved for a long period of time.

Communal IPAL which is located in Simokerto sub-district had been built since
2013. The communal IPAL was built with the funds from PT Pembangkitan Jawa Bali (PJB) Corporate Social Responsibility (CSR) in collaboration with Surabaya Government. The construction of communal IPAL involved the Faculty of Civil Engineering and Planning (FTSP) Institut Teknologi Sepuluh Nopember (ITS) as the experts, assistants, and program coordinators.

The type of communal IPAL is ABR filtration. $A B R$ is the abbreviation of Anaerobic Baffled Reactor. Filtration is a wastewater processing system that uses a septic tank, but there is an additional septum in the tank. The grease trap consists of four tanks, namely an equalization tub containing palm fibers, an anaerobic contactor tub containing zeolite, a contactor tub containing activated carbon, and a final settling tub.

The existence of communal IPAL in RT 01 RW 01, Simokerto sub-district has less attention from Surabaya Government even though this area has often won the competition of clean and green organized by Surabaya Government, especially in terms of the funding. Therefore, the chairman of RT $01 \mathrm{RW} 01$ took the initiative in the contribution for each house, and the idea was approved by the residents. The contribution is five thousand rupiahs per month. The money is used for operational costs and maintenance of communal IPAL.

\section{b. Environmental aspect}

Environmental sustainability refers to the ability of the environmental advantage to support the needs of human life at the present and in the future time. Community participation in wastewater management will be formed if the community has sufficient knowledge about wastewater management. It will contribute to the community behavior change towards wastewater. For this reason, it is necessary for the development of community behavior that is environmentally insightful. The behavior encourages someone to act and interact based on the same attitude and viewpoint regarding management responsibility.

The heterogeneity in the community is a challenge for the leaders in Simokerto subdistrict to realize a clean and safe environment. People were used to be fearful to enter the area in Granting passageway one. This area is part of RT $01 \mathrm{RW} 01$ in Simokerto. Finally, the chairman of this community tried to approach the villains, so that the area is more friendly and conducive for the guests from outside of the region right now.

There are various ways of socialization, for example by hanging out, talking with the neighbors about the importance of cleanliness and environmental safety, as the result, the 
behavior of the residents in Granting area is gradually changed into better behavior. This is indicated by the environmental condition in Granting area which is getting cleaner and tidy. The change is followed by an increase in security in the area. The spirit to change to be cleaner has made this place to be trusted to receive CSR assistance from $P T$ Pembangkit Jawa Bali (PJB) in the form of procuring communal IPAL.

The existence of communal IPAL in RT $01 \mathrm{RW} 01$ has provided some advantages for the community, such as the processing water that can be used to wash motorbikes, the cleaner and greener environment in Granting area (from a morning reportage of Trans TV channel, 2016). The advantages make many visitors from local and overseas who want to see directly the existence of clean environment in RT 01 RW 01, Simokerto sub-district, and eager to know about the management institution in communal IPAL.

\section{c. Socio-cultural aspect}

Socio-cultural sustainability aims to fulfill human beings' needs in both spiritual and cultural aspects. Thus, moral and community relationships can be established stably.

The component condition of communal IPAL in RT $01 \mathrm{RW}$ 01, Simokerto sub-district, has a lack of advantage because the maintenance activities are not routinely applied, even though the policy formulation has already been made. Environmental cadres have formulated policies in the form of scheduled management mechanisms, and written/ unwritten direction to use. Moreover, operational and maintenance activities in the form of community counseling are applied by the institution from the sub-district in collaboration with the experts. The cooperation is important to be held to provide direction for the community about the right time to do parameter testing, component checking, component cleaning, component refinement, and component substitution. Also, it provides socialization on the importance of the contribution that can be collected by the residents, especially adult age, female gender, unemployment, and the domicile which will be used for funding the communal IPAL in RT 01 RW 01, Simokerto sub-district.

\section{CONCLUSION}

The study concludes that the sustainability of communal IPAL in RT $01 \mathrm{RW}$ 01, Simokerto sub-district is assessed from the economic, environmental, and socio-cultural aspects. In term of the socio-cultural aspect, the component condition of communal IPAL has a lack of advantage due to non-routine maintenance activities.

According to the conclusion mentioned above, the study provides a recommendation that users of communal IPAL that has lack of advantages can be given a community education. The purpose is to provide knowledge to the public about the benefits of communal IPAL technology. The advantage is not only for watering plants and washing vehicles but also for providing job opportunities for the community if it is developed. The establishment of businesses in the form of washing vehicles, cultivating hydroponic plants, and fresh fish can be as the income for communal IPAL. Washing vehicles using water from the communal IPAL is placed on the communal IPAL land and the workers are the people in the resident. Cultivation of hydroponic plants and fresh fish utilizes water from communal IPAL is placed in several settlements. They can be harvested and distributed to wholesalers who sell the products to the consumers. The cash from vehicle washing, hydroponic plants, and fresh fish is used for communal IPAL construction.

\section{ACKNOWLEDGEMENT}

The authors greatly acknowledge the support from Naval Technology College, STTAL Surabaya Indonesia for providing the necessary resources to carry out this research work. The authors are also grateful to HangTuah University, UHT Surabaya, Indonesia who always give me opportunity to improve my research. And the last the authors would like to say thank to the anonymous reviewers and journal editorial board for their many insightful comments, which have significantly improved this article.

\section{REFERENCES}

Afandi, Y. V., Sunoko, H. R., \& Kismartini, K. (2014). Status Keberlanjutan Sistem Pengelolaan Air Limbah Domestik Komunal Berbasis Masyarakat Di Kota Probolinggo. Jurnal IImu Lingkungan, 11(2), 100. https://doi.org/10.14710/jil.11.2.100-109.

Creswell, J. W., \& Poth, C. N. (2018). Qualitative Inquiry and Research Design Choosing Among Five Approaches. Retrieved from https://drive.google.com/file/d/1NCokfEqf NtsCXbSemWEoqzjbEO13mXOV/view. 
Harudyawati, D. P. (2016). Pengelolaan Ipal Komunal yang Berkelanjutan di Dusun Sengkan, Sleman, Yogyakarta. UII, Yogyakarta. Retrieved from https://dspace.uii.ac.id/handle/12345678 9/108.

Matthew B. Miles, A. Michael Huberman, J. S. (2014). Qualitative Data Analysis: A Methods Sourcebook - Matthew B. Miles, A. Michael Huberman, Johnny Saldana Google Buku. Retrieved from https://books.google.co.id/books?id=p0w XBAAAQBAJ\&printsec $=$ frontcover\&hl=id $\# v=$ onepage $\& q \& f=$ false .

Nilandita, W., Pribadi, A., Nengse, S., Auvaria, S. W., \& Nurmaningsih, D. R. (2019). Studi Keberlanjutan IPAL Komunal di Kota Surabaya (Studi Kasus di RT 02 RW 12 Kelurahan Bendul Merisi Kota Surabaya). Al-Ard: Jurnal Teknik Lingkungan, 4(2), 46-54. Retrieved from www.al-ard.uinsby.ac.id.

Norman K. Denzin, Y. S. L. (2010). Handbook of Qualitative Research. Pustaka Pelajar.

Purwatiningrum, O. (2018). Gambaran Instalasi Pengolahan Air Limbah Domestik Komunal di Kelurahan Simikerto, Kecamatan Simokerto, Kota Surabaya. Jurnal Kesehatan Lingkungan, 10(82).

Widiwati, C. S. (2018). KONSEP PARTISIPASI MASYARAKAT DALAM OPERASIONAL DAN PEMELIHARAAN IPAL KOMUNAL DI KEL. SIMOKERTO, KEC. SIMOKERTO, KOTA SURABAYA. 